\title{
For konge og fædreland
}

\section{Valdemar Sejr hos B.S. Ingemann og Agnes Slott-Møller}

I 1205 holdt den danske konge Valdemar II Sejr bryllup med den bøhmiske prinsesse Dagmar. Dronning Dagmar døde i 1212, og i 1214 giftede kongen sig med den portugisiske prinsesse Berengaria (Bengerd). Knap ti år senere, en majnat $\mathrm{i}$ 1223, blev Valdemar Sejr og hans søn med Dagmar, Valdemar den Unge, kidnappet under et jagtselskab af sin tyske vasal Henrik af Schwerin. Fangerne blev løskøbt ved et forlig i 1225, der ud over en stor løsesum indebar afståelse af næsten alle de nordtyske besiddelser. Valdemar Sejr blev løsladt i december 1225, mens sønnen først blev frigivet i foråret 1226. Disse fire momenter i dansk middelalderhistorie, Valdemar Sejrs to bryllupper, tilfangetagelsen på Lyø og løskøbelsen, blev skildret med godt hundrede års mellemrum og $\mathrm{i}$ to forskellige medier af henholdsvis B.S. Ingemann i hans historiske roman Valdemar Seier fra 1826 og maleren Agnes Slott-Møller i hendes Valdemar Sejr cyklus malet mellem 1927 og 1934. At Ingemann og Slott-Møller behandlede samme stof, og begge havde en tydelig national dagsorden, gør det oplagt at sammenligne de to fiktionaliserede historiefremstillinger. Hertil kommer, at begge benyttede samme kilder, nemlig folkeviserne om Valdemar II.

I den følgende komparative læsning vil jeg fokusere på Ingemann og SlottMøllers fiktionaliserede historieskildringer og deres refleksioner over henholdsvis den historiske roman og historiemaleriets forhold til historieskrivningen. Jeg vil argumentere for, at de begge, men fra hver sin side, forsøgte at overskride grænsen mellem tekst og billede: Ifølge Ingemann må den historiske roman tilnærme sig maleriet, mens historiemaleriet for Slott-Møller må indoptage narrative elementer. Den afgørende forskel mellem de to er egentlig ikke mediet, men de hundrede år, der skiller dem. Ingemann og Slott-Møllers middelalderisme - forstået som genbrug og genskabelse af middelalderen - er på flere måder kompatible, men deres skildringer af Valdemar Sejr indskriver sig i hver sin historiske kontekst, henholdsvis romantikkens kulturelle nationalisme og mellemkrigstiden med dens spændinger mellem det pro- og det antinationale. 


\section{Ingemanns Valdemar Seier}

Valdemar Seier var Ingemanns første historiske roman. To år forinden, i 1824, havde han udgivet versfortællingen Valdemar den Store og hans Mænd - om Valdemar I, der samlede et borgerkrigshærget Danmark under én konge - og serien fortsatte med romanerne Erik Menveds Barndom (1828), Kong Erik og de Fredløse (1833) og Prins Otto og hans Samtid (1835) samt versfortællingen Dronning Margrete (1836). Tilsammen giver disse seks værker fiktionaliserede nedslag i Danmarks middelalderhistorie fra midten af det 12. århundrede frem til Kalmarunionen i slutningen af det 14., hvor Danmark, Norge og Sverige forenedes under en dansk regent. Samlet set tegner serien altså en opadgående linje fra splittelse og elendighed til skandinavisk enhed. Men hvert af de seks værker dramatiserer momenter i historien, hvor Danmarks overlevelse som nation stod på spil. Indledningen til Valdemar den Store slår tonen an, ikke kun for dette værk, men for serien som helhed:

\section{6 - Stig op af Graven, du Slægt, som døde! \\ Forkynd dit Fald og afmal din Brøde! \\ Advar os for Udslettelsens Dom, \\ Og vis os hvor fra din Frelse kom! \\ (Ingemann 1913, 11)}

I sin fortale til Prins Otto - Ingemanns mest udførlige refleksion over sin egen metode - skriver han, at det har været hans hensigt, at "lade hver Tidsalders Helte og virkelige Folke-Repræsentanter fremtræde som saadanne, uden at behøve at underordne det factisk Sande og Vigtige, for at fremhæve en vilkaarlig opfunden Helt" (Ingemann 1987, 531). Centralt i Ingemanns overvejelser over den historiske roman står forholdet mellem forfatterens bundethed af de historiske kendsgerninger og hans digteriske frihed eller mellem sandhed og poesi. Dette forhold er dog langt fra entydigt; sandhed og poesi er ikke nødvendigvis hinandens modsætninger. Som Ingemann understreger, rummer historien sin egen poesi: "Begivenhedernes eller den factiske Sandheds Poesie" (s. 534); men det fordrer en medskabende og indlevende digter at bringe den til udtryk. I sit Tilbageblik paa mit Liv og min ForfatterPeriode skriver Ingemann, at hans metode som historisk romanforfatter består i

64 Udfindelse af den skildrede Tidsalders egen Livspoesie, i en Opdagelse af den i de tørre Begivenheder og annalistiske Optegnelser skjulte Romantik, i Tildigtningen af alle de psychologiske og eventuelle Betingelser for den factiske Sandheds poetiske Aand og Liv. (Ingemann 1998, 306)

I den historiske roman føjes "Digtningens Hvorledes" til "Historiens Hvad", og i denne tilføjelse får den historiske digter sin "poetiske Frihed tilbage" (Ingemann 1987, 532). ${ }^{\mathrm{I}}$

I Valdemar Seier knytter den historiske romans "Hvorledes" sig i særdeleshed til fremstillingen af kongens person. ${ }^{2}$ Ingemann skildrer Kong Valdemar som en sammensat eller ligefrem splittet karakter - splittet mellem krigerkongen og fredsfyrsten, den succesrige feltherre og den fremsynede lovgiver. De to sider af kongens personlighed kommer i romanen til udtryk i hans ægteskaber med to vidt forskel- 
lige kvinder, den blide og fromme Dagmar og den mørke, lidenskabelige valkyrie, Beengjerd (Bengerd). ${ }^{3}$ De historiske annaler melder intet om de to dronningers personligheder; Ingemann har her taget folkeviserne til hjælp - de historiske folkeviser, som han opfattede som samtidige med de begivenheder, de skildrer, og dermed som fuldgyldige historiske kilder. ${ }^{4}$ Werner Abrahamson, Rasmus Nyerup og Knud Lyne Rahbeks folkevisesamling Udvalgte danske Viser fra Middelalderen (1812-14) har fire viser om Dronning Dagmar, herunder to om hendes formæling med kongen og ankomst til Danmark. ${ }^{5}$ Ingemanns version lægger sig op ad folkevisernes, men med tildigtninger og langt flere detaljer. I Valdemar Seier betages kongen af et portræt af den lyse og uskyldsrene prinsesse. Han sender sin betroede mand Strange Ebbesøn til Böhmen for at fri og føre bruden til Danmark. I mellemtiden møder han den portugisiske prinsesse Beengjerd og forelsker sig lidenskabeligt. Han sender bud til Strange og anmoder ham om at afbryde, men for sent; kongen er allerede lovformeligt formælet med Dagmar. Det er derfor med meget blandede følelser, han modtager sin brud. Det mørke og det lyse strides i hans sind. Men ved synet af Dagmars "rene Engleaasyn" opløser stormen i hans indre sig i "inderlig Veemod": "Han syntes, at en salig Helgeninde var nedstegen til ham for at ydmyge og beskæmme hans ustadige Hjerte. Et renere uskyldigere Qvindeaasyn havde hans Øine aldrig seet" (Ingemann 1987, 169).

Ikke overraskende har den milde og uskyldsrene Dagmar Ingemanns udelte sympati. I overensstemmelse med folkeviserne fremstilles hun som en fredens dronning, der viser omsorg for de fattige og elskes af folket for sin godhed. Mere overraskende er det, at hans portræt af den mørke og lidenskabelige dronning Beengjerd ikke er entydigt negativt. I folkevisen skildres hun som et rent monster, der som morgengave kræver, at det danske folk brandbeskattes. Det er sigende, at denne scene ikke figurerer i Ingemanns roman. I stedet vælger Ingemann at vise Valdemar og Beengjerds dans under bryllupsfesten: "Alle betragtede med Forundring det ædle kongelige Par. De dandsede ene, og et stoltere Syn havde ingen dansk Ridder seet" (Ingemann 1987, 316). Ingemanns Beengjerd omgiver sig med pragt, og hun indfører en mere formel og fornem omgangsform ved hoffet. Hun skildres også som forhadt af den jævne dansker, men ansvaret for den øgede beskatning afstår han fra at lægge på hendes skuldre alene. Det voksende skattetryk skyldes kongens "store krigeriske Foretagender" og det "stedse voxende Krigsstyr", som også de lavere folkeklasser måtte bidrage til at udrede (Ingemann 1987, 327). Som den dristige og i øvrigt fritænkeriske valkyrie, som Ingemanns Beengjerd er, appellerer hun til feltherren og erobreren i Valdemar Sejr, som Dagmar appellerede til fredsfyrsten. Beengjerd gør kongen mere mandig: "Det var som Kongens kjække ungdommelige Helteaasyn nu først havde modtaget det store kongelige Udtryk og den mandige urokkelige Fasthed, som var hans store Fader egen" (s. 327). Ingemann underkender ikke disse kvaliteter, skønt hans største sympati er reserveret fredsfyrsten.

Skildringen af Valdemar Sejrs to dronninger demonstrerer, hvad den historiske roman ifølge Ingemann kan til forskel fra den historiske lærebog. Romanen giver $\mathrm{k} ø \mathrm{~d}$ og blod til personer, der blot er navne i de historiske annaler. Den giver forfatteren frihed til at leve sig ind i de historiske karakterer, til at skildre dem indefra og delagtiggøre læserne i deres tanker, følelser og indre drivkræfter. Den historiske 
roman kan endvidere stille fortiden anskueligt for øje. Det er påfaldende, så ofte og så konsekvent Ingemann omtaler sin egen metode som historisk romanforfatter med termer, der alluderer til den visuelle kunst. I sit Tilbageblik skriver Ingemann om romangenren, at "[d]en Udførlighed, der er denne Fremstillingsart naturlig, tillader en rolig omstændelig Udmaling af Menneskelivets mangfoldige characteristiske Enkeltheder". Han priser den "Magelighed, hvormed en Læser kan see Romanen udfolde sine Billeder" og tilføjer, at "Romanformen" besidder "en saadan Rigdom af Farver til det historisk-poetiske Malerie", og at han derfor valgte "denne Form til Fremstillingen af mine fleste øvrige historisk-poetiske Billedrækker" (Ingemann 1998, 305-6, mine udhævninger). Tilsvarende bruger han i Fortalen til Prins Otto ord som "Forgrund" og "Baggrund" (Ingemann 1987, 531), "Udmaling" og "Billede", "Farve" og "Farveskjær" (s. 532). Med sin opfattelse af den historiske romanforfatter (eller i det mindste sig selv) som en slags historiemaler lægger Ingemann op til at overskride den grænse, som Gotthold Ephraim Lessing trak med sit berømte essay Laokoon: oder über die Grenze der Malerei und Poesie (1766), nemlig grænsen mellem billedkunst og litteratur. Ifølge Lessing betjener billedkunsten og litteraturen sig af hver sit sprog eller tegnsystem. Mens billedkunstens sprog består af visuelle tegn, der sameksisterer i rum, benytter litteraturen sig af arbitrære tegn, ord, der følger efter hinanden i tid. Det følger derfor for Lessing, at billedkunstens mimesis adskiller sig fra den litterære. De to kunstarter har hver sit genstandstandsfelt, henholdsvis genstande eller legemer, der sameksisterer i rum, og handlinger, der udfolder sig i tid. De begrænsninger, som de to kunstarter hver især er underlagt, bliver tydelige, når de forsøger at bevæge sig ind på hinandens domæne. Den visuelle kunst kommer ifølge Lessing til kort, når den prøver at fremstille handlinger. Omvendt slår litteraturen fejl, når den forsøger at afbilde objekter med ord. Den sidstnævnte problemstilling har W.J.T. Mitchell taget op i artiklen "Ekphrasis and the Other" (1992). Mitchell taler her om litteraturens ekfrastiske håb og ekfrastiske frygt som to sider af samme mønt. Mens det førstnævnte betegner litteraturens begær efter at overskride grænsen til den visuelle kunst, er sidstnævnte det "counterdesire", der indtræffer, når man konfronteres med konsekvenserne af en udviskning af forskellen mellem den sproglige og visuelle fremstilling - frygten for, at det litterære kunstværk skal stivne og miste sin narrative fremdrift (Mitchell 1992, 697-98).

De detaljerede og 'tykke' beskrivelser - af landskaber, bygningsværker, interiører, fysiognomier, klædedragter, våben og alskens artefakter - er utvivlsomt et af den historiske romans centrale greb. Men der er klart tale om en balancegang: Langstrakte beskrivelser bremser den narrative progression og sætter potentielt tålmodigheden på prøve hos den læser, der i romanen primært søger et medrivende og elementært spændende plot. Lessings anbefaling til digteren er at indfælde eventuelle beskrivelser af visuelle objekter i en handling. Når det gælder skildringen af det sceneri, der danner rammen om det fatale jagtmiddagsselskab på Lyø, følger Ingemann Lessings opskrift:

Den gamle Andreas Kammermester havde imidlertid havt travlt med at indrette det kongelige Telt, hvorunder Herskabet agtede at spise til Aften og overnatte. Den gamle troe Kammermester havde beredet Alting paa det Bedste til det kongelige Herskabs Op- 
muntring og Vederqvægelse. Han havde udsmykket Teltet med Skarlagenstæpper og med Mailøv, og sørget for, at Kongens og Prindsens Leie blev beqvemt og pynteligt; han havde med Bjørn Mundskjænk ladet Vinen øse i Sølvkanderne, og de gyldne Bægere polere og fremsætte, medens han ikke havde forsømt af og til at knurre paa Madsvenden og Kjøgemesteren. [...] [S] elv for Kongens Falke og Jagthunde havde han omhyggeligt sørget. (Ingemann 1987, 414)

Hermed er scenen sat til et af romanens dramatiske højdepunkter. Som Ingemann skildrer selve jagtmiddagen, er den ulykkessvanger under sin feststemte overflade. Der bliver drukket tæt; kun kongens vasal, grev Henrik af Schwerin, drikker på skrømt og fingerer sin fuldskab. Og kong Valdemar forsømmer at læse bordbønnerne. Samme nat bliver kongen og hans fjortenårige søn overrumplet af grev Henrik og hans mænd og i ly af mørket ført med skib til Tyskland.

Kongen og prinsens langstrakte fangenskab er i Ingemanns roman begyndelsen til enden på krigerkongen Valdemar Sejr. Som sine væsentligste kilder til de historiske romaner har Ingemann selv nævnt historikerne Arild Huitfeldt (1546-1609) og Peter Frederik Suhm (1728-98). ${ }^{6}$ Begge lader formode, at frikøbelsen tog så lang tid, fordi ikke alle danske var lige ivrige efter at befri kongen (Nielsen 1987, 511). Ingemanns version ignorerer på dette punkt historikerne og støtter sig i stedet til folkevisen "Kong Valdemars Fængsel" (ANR LXXII / DgF 141), der betoner det danske folks offervilje og udelte glæde ved kongens befrielse. I både visen og romanen giver danske kvinder deres smykker, så løsesummen kan betales. Den største bet for kongen er dog afgivelsen af erobrede landområder i Nordtyskland og et aftvunget løfte om ikke at fors $\varnothing g e$ at vinde dem tilbage. Ingemanns Valdemar Sejr vender hjem fra fangenskabet fast besluttet på at bryde dette løfte og påbegynde tilbageerobringen af det tabte. Romanens endelige vendepunkt kommer med slaget ved Bornhøved i 1227, hvor danskerne lider nederlag, og kongen selv bliver hårdt såret. Bornhøved er romanens peripeti, og dens anagnorisis følger umiddelbart efter. Som i en åbenbaring forstår kongen sit nederlag som en "retfærdig Himlens Revselse" (Ingemann 1987, 482), og idet han fremdrager og betragter portrættet af Dronning Dagmar, fuldbyrdes hans transformation fra krigerkonge til fredsfyrste. Striden mellem de to sider af kongens personlighed er omsider bilagt, og Dagmarsiden har sejret. For at tydeliggøre sin pointe henlægger Ingemann i strid med de historiske kendsgerninger hele Valdemars lovgivningsarbejde til den sene del af hans regeringstid (Nielsen 1987, 510). Valdemar Sejr bliver til “Valdemar Lovgiver” (Ingemann 1987, 501).

\section{Slott-Møllers Valdemar Sejr serie}

I helt kort form lyder historien om Agnes Slott-Møllers kunstneriske karriere som følger: Som selvudnævnt prærafaelit var Slott-Møller i 1890erne en del af den symbolistiske avantgarde i dansk malerkunst, medstifter af Den Frie Udstilling (1891) og havde i øvrigt tidens mest markante intellektuelle, Georg Brandes, som sin ven og mentor. Efter århundredeskiftet bevægede dansk malerkunst sig i en anden retning, men Slott-Møller forblev til det sidste tro mod sin middelalderisme, og kunstnerisk set blev hun efterhånden mere og mere marginaliseret.7 Valdemar Sejr cy- 
klussen blev til i den sidste del af hendes karriere. For en kunstner at kaste sig over et projekt af dette format (også helt bogstaveligt: det største af billederne måler ca. 2,75 x $5 \mathrm{~m}$ ) uden at have en opdragsgiver, er ret uhørt. Ikke desto mindre var det, hvad Slott-Møller gjorde - i håb om, at billederne måtte få plads i en offentlig sammenhæng (Overgaard 2008, 47). I dag hænger Kong Valdemar med sin Søn ved Jagtmåltidet på Lyø i Maj 1223 og Valdemar Sejrs Hjemkomst fra Fangeskab på Nyborg Slot. Kong Valdemars Bryllup med Dronning Dagmar er ejet af Ringsted Kommune, mens Kong Valdemar og Dronning Bengerd i 1984 blev solgt til udlandet; dets nuværende placering kendes ikke (Overgaard 2006, 76-77). Foruden disse to par omfatter serien et tredje: Unge Kong Valdemars Død på Refsnæs (1930) og Spaadommen om Bengerdsønnerne (1934), begge i dag på Nyborg Slot. ${ }^{8}$

Agnes Slott-Møller var ikke kun billedkunstner; hun havde også en skarp og til tider polemisk pen. I 1923 udgav hun bogen Folkevisebilleder, der i en form for kunstnerisk selvbiografi fortæller om tilblivelsen af og hensigten bag en række af hendes vigtigste værker. Valdemar Sejr cyklussen er af gode grunde ikke omtalt, men bogen giver et væsentligt indblik i Slott-Møllers kunstneriske projekt og selvforståelse og i den opfattelse af middelalderen, der ligger til grund også for det sene værk. I bogen genkalder hun således sit første og skelsættende møde med den italienske middelalderkunst. I 1888 rejste hun og hendes mand, maleren Harald Slott-Møller, til Italien for ved selvsyn at opleve den italienske middelalderkunst. Hvad Slott-Møller fandt i museer og kirker i Norditalien, var det modsatte af en mørk middelalder. Som hun fortæller, åbnede billederne en "Verden af Kunst og Skønhed", en verden med præg af "ædel Ungdom, af evig Ungdom, af Alvor og dyb Følelse" og med en farvepragt uden lige; "den straalede af Guld over Guld, den blomstrede som Paradisets Enge" (Slott-Møller 1923, 12). Men først og fremmest fandt Slott-Møller i det italienske middelaldermaleri en kunst, der "med Lidenskab tog parti for det gode mod det onde", og som "tjente en stor Idé" (s. 13). Efter eget udsagn havde hun altid selv $\emptyset$ nsket, at hendes kunst skulle tjene en stor idé, nemlig "Fædrelandskærligheden", og i middelalderens billedkunst så hun nu "fremstillet og prist den hellige Histories Himmel-Konger og Martyr-Helte, som jeg havde drømt om at se Konger og Helte i vor danske Historie fremstillet og prist" (s. 13). Skal man tro Slott-Møllers erindring, besluttede hun på stedet at blive "en dansk 'Præ-Raphaelit"' (s. 13) og overføre middelalderkunstens idé til dansk historiemaleri.

For både Ingemann og Slott-Møller stod den danske middelalder og navnlig Valdemarernes tidsalder i et helt særligt lys. I sit essay "Kongen og Folket", optrykt i bogen Nationale Værdier fra 1917, spørger Slott-Møller retorisk: "naar var Danmark størst og sejrigest?” Og hun svarer selv: "Under store Konger! I den tidlige Middelalder under Knud den Store, senere under Valdemar den Store, Valdemar Sejr, Valdemar Atterdag, Margrethe!" (Slott-Møller 1917, 55). Essayets grundtanke er de store personligheders afgørende betydning for historiens gang. De største ting er sket i kraft af de store enere, hævder hun - og når den store ener var landets kronede regent, som det var tilfældet under Valdemarerne og Margrethe, blomstrede landet og folket både indadtil og udadtil. Netop Valdemar Sejrs regeringstid ser hun som "det største Bevis paa, hvad den store Konges Personlighed betyder for Landet" (s. 55). Da Valdemar Sejr blev slæbt i fangenskab, var "Danmark som med eet Slag 


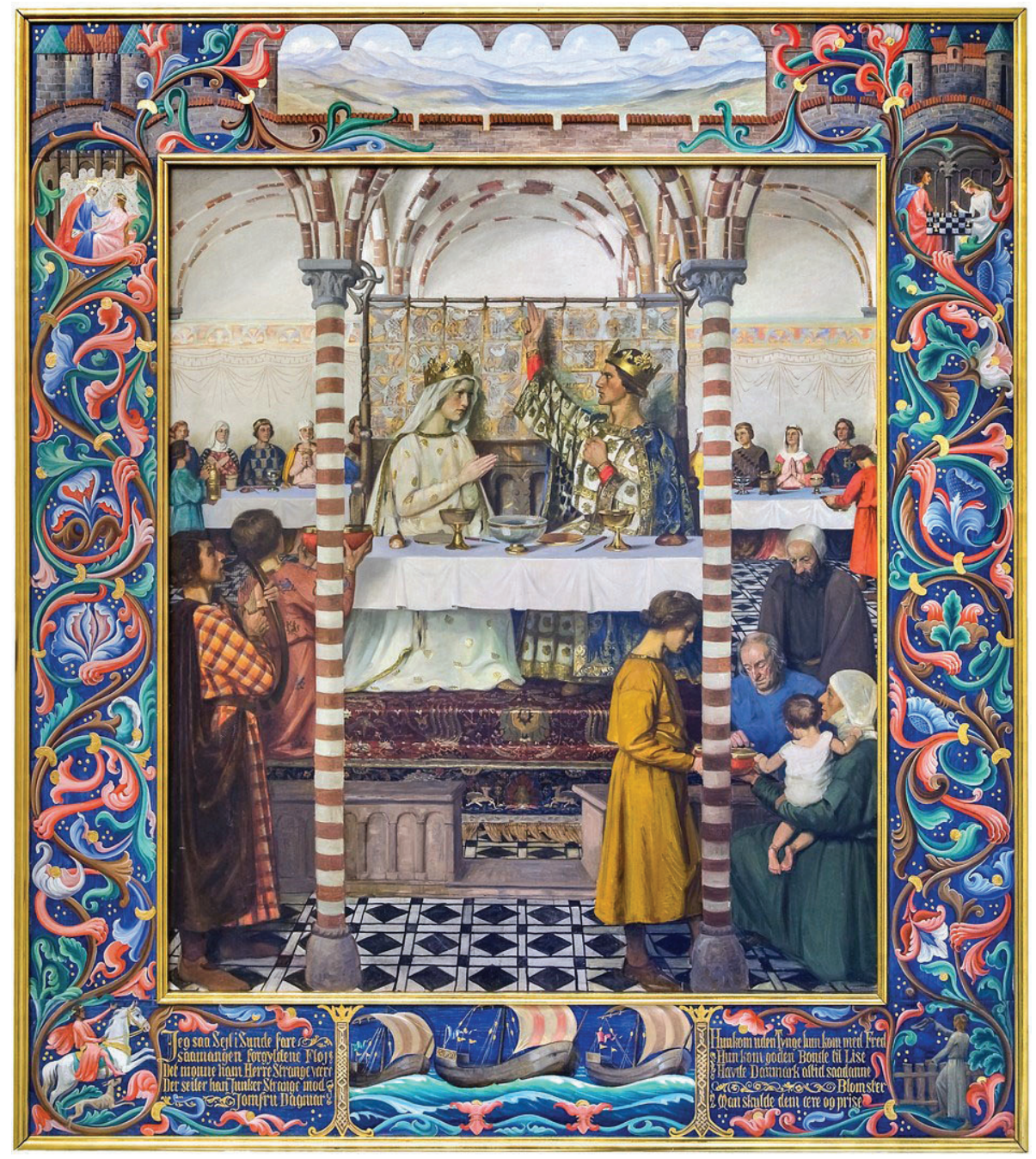

Agnes Slott-Møller, Kong Valdemars Bryllup med Dronning Dagmar, 1932. Ringsted Kommune.

slaaet til Jorden" (s. 55). Skønt det danske ridderskab ikke savnede udmærkede mænd, kunne intet erstatte tabet af kongen, og det danske folk var villige til at ofre både land og ejendele "for at faa den ene Mand, Kongen, tilbage" (s. 55).

Opfattelsen af Valdemar Sejr som den store ener kommer ikke overaskende til udtryk i Slott-Møllers Valdemar Sejr cyklus. Hvert af de seks billeder har Kong Valdemars figur som sit centrale motiv, og kongen er ikke blot fremstillet med faste, mandige træk, der udstråler styrke og myndighed; billederne er også komponeret på en sådan måde, at kongens skikkelse visuelt set rager op over alle andre figurer. Den heroiserende fremstilling af Valdemar Sejr har Slott-Møller til fælles med Ingemanns roman, der ustandselig bruger præfixet helte- i skildringen af kongens fremtræden. Til forskel fra Slott-Møller har Ingemann dog mere end én gennemgående protagonist. Hans historiske romaner har således altid mindst én socialt set lavere placeret helt, der ender med at spille en væsentlig rolle for de historiske begivenheder. I Valdemar Seier er det den forældreløse Carl af Riise, der udfylder denne plads. Slott-Møllers placering af 


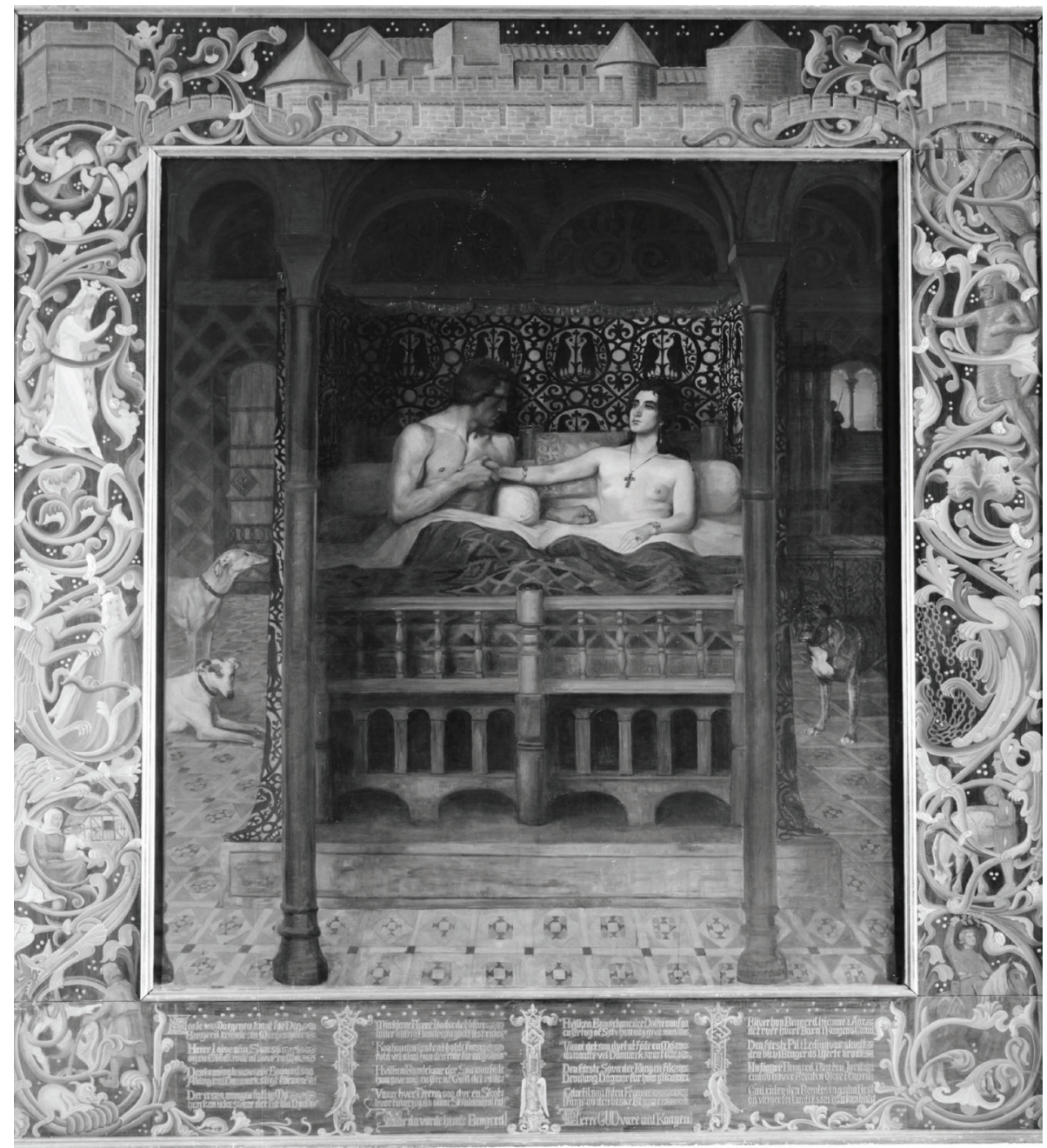

Agnes Slott-Møller, Kong Valdemar og Dronning Bengerd, 1931. Foto: (C) Bruun Rasmussen Kunstauktioner

kongen i den altdominerende rolle kan naturligvis til dels forklares med henvisning til mediet - maleriet kontra romanen. Men som "Kongen og Folket" antyder, har hendes valg også en ideologisk klangbund i en brandesiansk "aristokratisk radikalisme" med dens dyrkelse af store enestående personligheder (Dahlerup 2008).

Slott-Møllers Valdemar Sejr er dog ikke kun et helteportræt; hun har også villet skildre kongens på mange måder tragiske skæbne. "Valdemar Sejr er en fremragende Personlighed, og hans Live er fyldt med Lys og Mørke”, udtalte Slott-Møller i et interview fra 1932 om Valdemar Sejr serien (citeret efter Overgaard 2006, 64). Det mørke eller tragiske aspekt træder endnu tydeligere frem, når man tager hele serien i betragtning og inddrager de to billeder, der viser den aldrende konge, som henholdsvis står med sin døde søn og tronfølger i armene og modtager en uheldsvanger spådom over hans sønner af andet ægteskab. Som Ingemann har Slott-Møller forsøgt at trænge ind under huden på sin protagonist og dermed give historiemaleriet en psykologisk dimension. 
Historiemaleriet er per definition et fortællende maleri og som sådant en genre, der udfordrer Lessings arbejdsdeling mellem litteratur og billedkunst. Agnes SlottMøller var ikke den første danske historiemaler, der valgte Valdemar Sejr som motiv. Christian August Lorentzens Dannebrog falder ned fra himlen under Volmerslaget ved Lyndanisse (Tallin) i Estland den 15. juni 1219 (1809) er, som titlen antyder, en handlingsmættet skildring af et af Valdemar Sejrs vigtigste slag. I forgrunden er kongen placeret midt i slaget på en græsklædt høj. Mellemgrunden viser heftig kamptummel, og i baggrunden anes kongens ærkebisp Anders Sunesen, der strækker sine arme mod himlen, hvorfra Dannebrog daler. Kontrasten mellem lys og skygge er højdramatisk. Dannebrog synes at falde fra en flænge i det mørke skydække, og lyset rammer både flaget og kongen, der således forbindes. I sammenligning med Lorentzens billede forekommer Kong Valdemars Bryllup med Dronning Dagmar og Kong Valdemar og Dronning Bengerd at være påfaldende statiske. Det første viser kongen og dronning Dagmar til højbords under bryllupsfesten; kun scenen med bespisning af de fattige i billedets højre hjørne tilfører billedet et narrativt element. I det andet ser vi Valdemar og dronning Bengerd siddende ret op i brudesengen; hun rækker sin højre hånd frem i en bydende gestus, og han kysser den. Begge billeder er komponeret på omtrent samme vis. Der er ingen klar opdeling i forgrund, mellemgrund og baggrund og dermed intet dybdeperspektiv; tværtimod virker begge malerier flade. Kong Valdemar og Dronning Bengerd kendes kun i sort-hvid fotografisk gengivelse, men i Kong Valdemars Bryllup med Dronning Dagmar er farverne klare og hele scenen klart belyst. Som prærafaelitisk historiemaler har Slott-Møller altså givet afkald på alle de dramatiske effekter, som en Lorentzen kunne benytte sig af. Dramatikken hos Slott-Møller er ikke $i$ de respektive billeder, men i kontrasten mellem dem, i særdeleshed i kontrasten mellem de to dronninger, der træder så meget desto stærkere frem på baggrund af de næsten identiske billedkompositioner. Dagmar og Bengerd forholder sig til hinanden som hvid til sort og som god til ond. Bengerd er Valdemars "onde Aand, som Dagmar var hans gode", skriver Slott-Møller i sit essay "Om Dronning Berengaria” i Nationale Værdier (Slott-Møller 1917, 44). Skønt skrevet i 1914 passer disse ord fuldstændigt på Kong Valdemars Bryllup med Dronning Dagmar og Kong Valdemar og Dronning Bengerd. Mens Slott-Møllers syn på Dagmar er meget lig Ingemanns, er hendes fremstilling af Bengerd forankret i folkevisens version og dermed mindre nuanceret end hans.

Trods den forholdsvis statiske komposition især i dronningebillederne er SlottMøllers historiemalerier på ingen måde blottet for det fortællende. I skildringen i Folkevisebilleder af sit første møde med den italienske middelalderkunst betoner Slott-Møller sin betagelse af det narrative element i de italienske mestres billeder: “Den mægtige Stil, den storslaaede Kraft og Klarhed, Simpeltheden i Giotto's storliniede Skikkelser syntes os det ædleste af Alt; her saa vi i hvilken Grad det havde ligget Kunstneren paa Sinde at fortælle sit Billede" (Slott-Møller 1923, 12). At fortælle sit billede var også Slott-Møllers ambition, og til dette formål benyttede hun flere teknikker. Hun eksperimenterede med forskellige formater, fx triptykonet, der med inspiration fra altertavlen skildrer tre situationer fra samme historie, og som skal 'læses' fra venstre mod højre som en tegneserie. ${ }^{9}$ Først og fremmest brugte hun

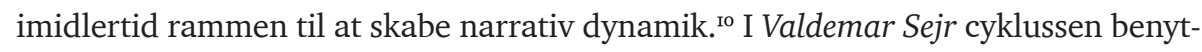




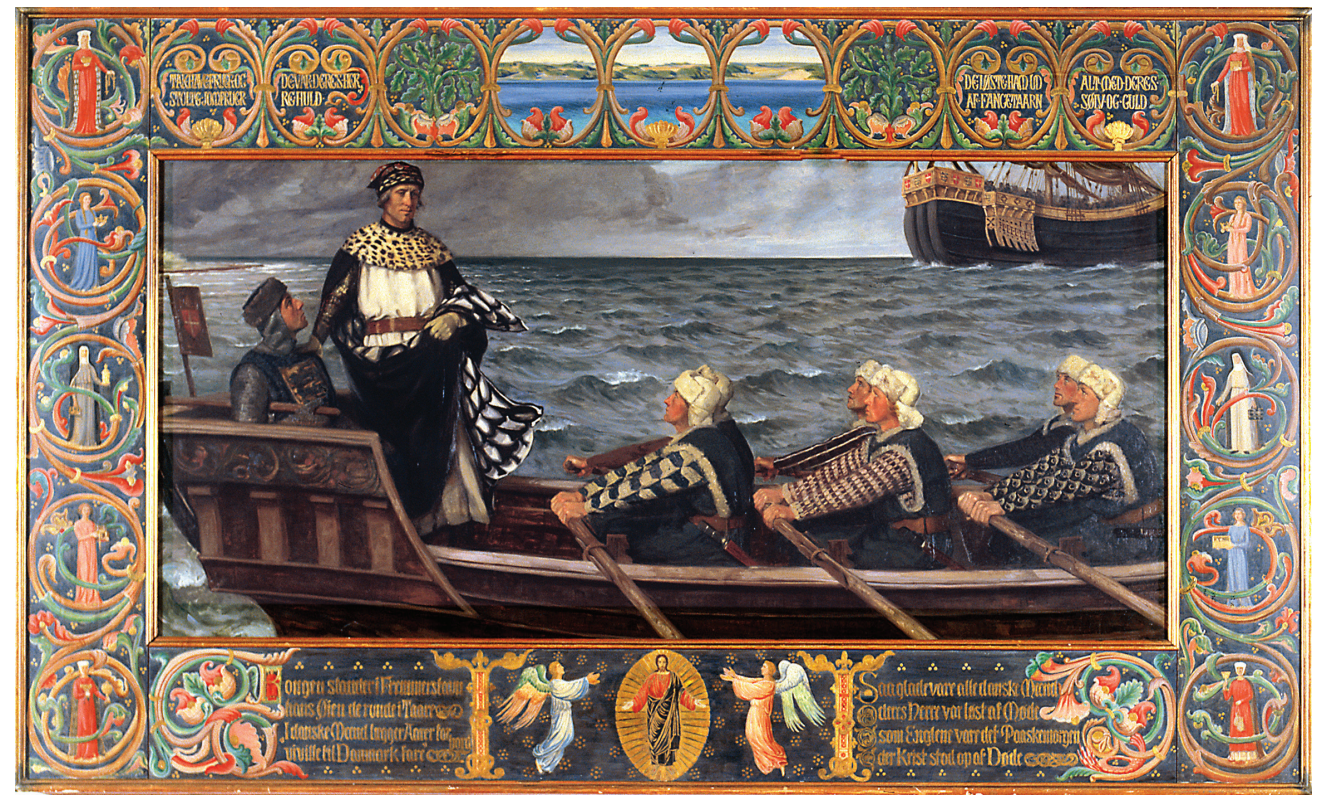

Agnes Slott-Møller, Valdemar Sejrs Hjemkomst fra Fangenskab, 1929. Nyborg Slot / Østfyns Museer

tes brede malede rammer, der udgør en integreret del af maleriet, og som i samspillet med centralmotivet skaber en lighed med middelalderens bogkunst.

Tre elementer indgår i disse rammer: ornament, vignet og tekst. Ornamentet har karakter af en arabesklignende bort, der slynger sig hele vejen rundt om centralmotivet. Til forskel fra bortens rent dekorative funktion har både tekster og vignetter et fortællende såvel som et dekorativt sigte. Teksterne er i alle tilfælde strofer fra de folkeviser, som billederne er baseret på. Kong Valdemar og Dronning Bengerd citerer således store dele af visen om Bengerd, og teksten angiver, hvorledes billedet skal læses. Bengerd-visen er udformet som en dialog mellem Kong Valdemar og hans nye dronning: Hun kræver sin morgengave i form af skatter, der skal tilfalde hende, og han forklarer, hvorfor han ikke kan opfylde hendes $\emptyset$ nske. Bengerd fremtræder her som den hårdhjertede dronning, der blot ser det danske folk som en indtægtskilde, mens Valdemar præsenteres som folkets beskytter. Det er denne morgengave-scene, som Slott-Møller har valgt at skildre. Samtidig beretter den indsatte folkevisetekst om hændelser, der rækker ud over billedet, nemlig Bengerds død, der i sammenhængen fremstår som både en retfærdig straf og en udfrielse. "Og nu ligger Berngerd i sorten Jord, / Endnu haver Bonden Oxe i Gaard" (ANR LXXI / DgF 139), lyder to af de vers, der citeres i rammen. Endelig er der vignetterne, der supplerer maleriernes hovedmotiv og indsætter det $i$ en handlingsrække, idet de angiver, hvad der er gået forud, eller hvad der følger efter. Valdemar Sejrs Hjemkomst fra Fangenskab viser kongen stående oprejst i den båd, der ror ham ud til det ventende danske kongeskib. Vignetterne forestiller her kvinder, der frembærer deres skatte - en illustration af folkevisens “Tak have ædle Jomfruer og Fruer / De vare deres Herre saa huld; / De sparte for hannem ej Linde eller Kjæde / Og ikke deres Hovedguld" (ANR LXXII / DgF 141). Vignetterne viser her en 
handling, der er gået forud for kongens frigørelse, nemlig udredningen af løsesummen. Samtidig er de et statement om det danske folks kærlighed til deres konge. Denne kærlighed kommer symbolsk til udtryk i vignetten nederst på billedrammen: Kristus i en mandola, flankeret af to engle. Ved første øjekast forekommer denne illustration at være uden forbindelse til hovedmotivet, men den giver mening i lyset af folkevisens tekst, der også citeres i rammen: "Saa glade vare alle de danske Mænd, / Deres Herre var løst af Møde, / Som Englene vare Paaskemorgen, / Vor Herre stod op af Døde" (s. 141).

Kong Valdemar ved Jagtmåltidet på Lyø i Maj 1223 er det største og også mest ambitiøse af malerierne i Valdemar Sejr serien. Samtidig er det det, der har det svageste folkevisebelæg: Visen om kongens fangenskab nævner blot, at han blev taget til fange og fortæller intet om omstændighederne omkring hans tilfangetagelse. Slott-Møllers kilde til skildringen af selve jagtmåltidet kunne meget vel være Ingemanns Valdemar Seier. Ganske vist havde tidens dom over Ingemanns historiske romaner været hård. Det moderne gennembrud og i særdeleshed Georg Brandes, Slott-Møllers gamle mentor, foragtede romanerne, og den popularitet, som de i samtiden havde nydt i den brede befolkning, var dalet betragteligt. Ingemanns historiske romaner var dog ikke gået helt i glemmebogen, og i 1910erne blev de faktisk genoptrykt. Tager man Agnes Slott-Møllers folkevisebegejstring og hendes på mange måder romantiske syn på dansk middelalderhistorie i betragtning, forekommer det usandsynligt, at hun ikke skulle have læst Valdemar Seier ${ }^{\text {II }}$ Kong Valdemar ved Jagtmåltidet på Lyø i Maj 1223 understøtter denne formodning. Alle de elementer, som Ingemann nævner i sin beskrivelse af scenen for måltidet, er nemlig medtaget i Slott-Møllers skildring: kongen og prinsens bekvemme sæde, sølvkanden, de blankpolerede gyldne bægre, jagthund(e) og falk(e), sågar det frisk afskårne "Mailøv" (Ingemann), der dog hos Slott-Møller udgøres af kongelige egegrene snarere end grene fra det mere folkelige bøgetræ.

Jagtmåltidet på Lyø blev Valdemars sidste i frihed frem til hans løsladelse i december 1225, og Slott-Møller har valgt at skildre dette 'sidste måltid' med forlæg i maleriske fremstillinger af den sidste nadver, i særdeleshed Leonardo da Vincis vægmaleri i klosteret Santa Maria delle Grazie i Milano (1495-98). I alt tretten personer er placeret omkring det rektangulære bord, og Kong Valdemar sidder på samme plads som Leonardos Jesus: i midten. Hvad Slott-Møller skrev i Folkevisebilleder, har hun her helt bogstaveligt eksekveret - nemlig "fremstillet og prist" "Konger og Helte i vor danske Historie", som middelaldermaleriet havde "fremstillet og prist den hellige Histories Himmel-Konger og Martyr-Helte" (Slott-Møller 1923, 13). Mens det hos Ingemann handler om Gud, konge og folk, synes Gud (og i et vist omfang også folket) at være forsvundet ud af ligningen hos Slott-Møller. Eller måske rettere: de tre er forenet i kongens person. Sammenkædningen af jagtmåltidet på Lyø med den sidste nadver understreges af vinen, der drikkes, og brødet på bordet. Og naturligvis har jagtmåltidet sin egen Judas - den svigefulde tyske vasal Henrik af Schwerin, der, som Judas hos Leonardo da Vinci, er placeret til venstre i billedet. De mange referencer til den sidste nadver tjener naturligvis til at hæve kong Valdemar til overmenneskelige højder, men de bidrager også væsentligt til billedets narrativ. Kong Valdemar ved Jagtmåltidet på Lyø i Maj 1223 er det mest dynamiske af Slott- 


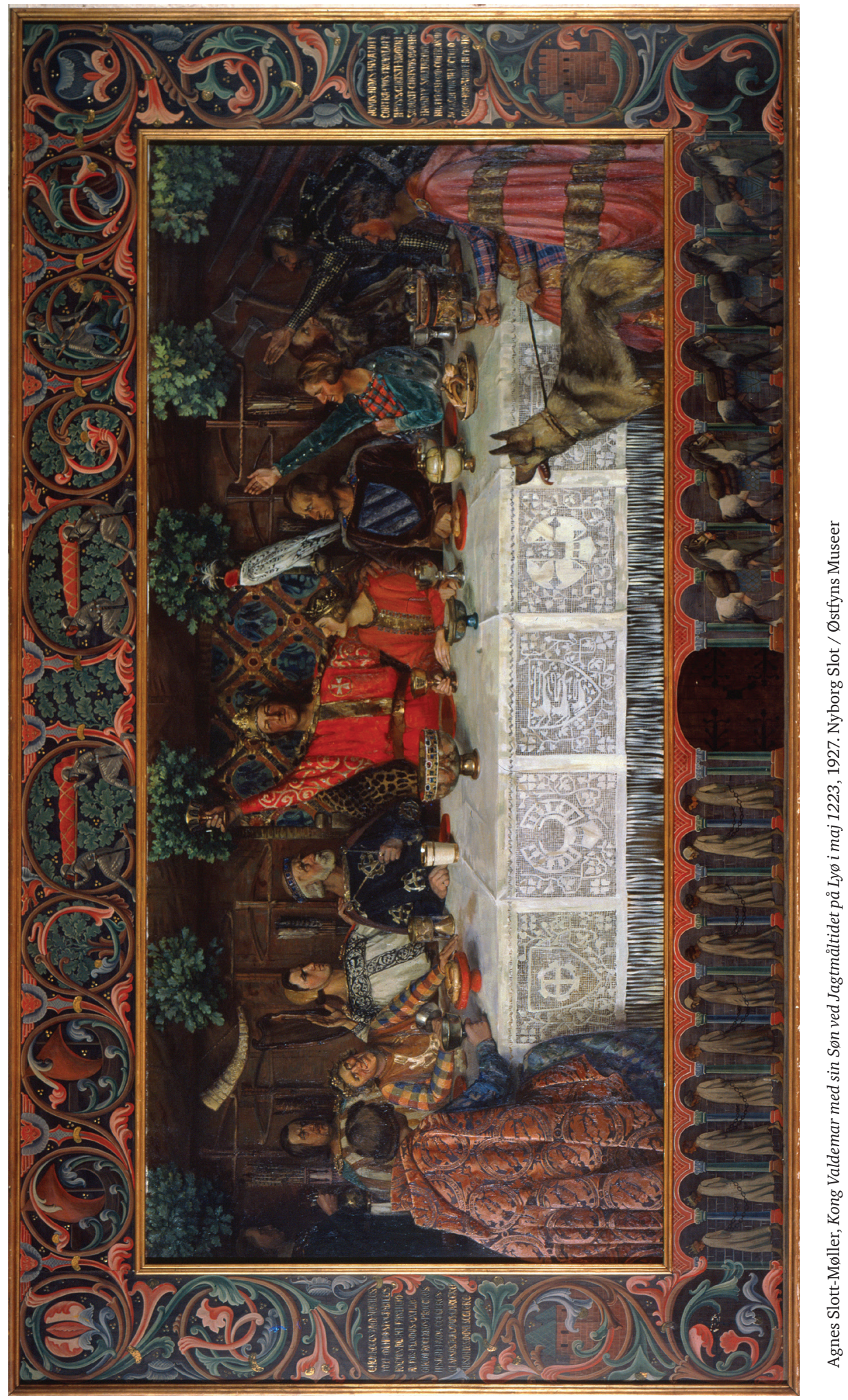


Møllers Valdemar Sejr billeder og også det mest detaljerede. De kostbare artefakter og tekstiler er skildret med sikker sans for deres materialitet og skønhed. Især fanges blikket af kongens og den unge prins' karminrøde og guldkantede tunikaer og den pragtfulde brokadelignende kappe, der bæres af ridderen til venstre i billedet. De tretten personer omkring bordet er alle individualiserede, og de interagerer på forskellig vis. Dog er alles blikke rettet mod kongen, der løfter sit gyldne bæger til en skål. Ved første øjekast har vi at gøre med en lystig scene, men lystigheden undermineres af kompositionens reference til den sidste nadver. Den dystre tone, som denne reference anslår, kommer helt og fuldt til udtryk i rammens vignetter. Her fortælles i billedform om tilfangetagelsen. I toppen ser man grev Henriks harniskklædte mænd i al hast bære to indsvøbte fanger ned til et ventende skib (de karminrøde svøb afslører, at de to fanger er kongen og prinsen). I bunden går en række lænkede fanger med kongen og prinsen forrest den tunge gang til fangehullet.

\section{Ingemann og Slott-Møller i historisk kontekst}

I en berømt fortælling af Jorge Luis Borges sætter den fiktive 1900-tals forfatter Pierre Menard sig for at genskrive Don Quixote og ender med at skabe et værk, der ord til andet er identisk med Cervantes'. ${ }^{\text {I2 }}$ Som fortællingen understreger, er Menards Quixote alligevel et fuldstændigt andet værk end Cervantes' - fordi det er blevet til i det 20. århundrede og må læses i den sammenhæng. Agnes Slott-Møllers Valdemar Sejr er ikke identisk med B.S. Ingemanns, men der er trods alt helt markante ligheder, ikke kun mellem de tos idealiserende skildringer af en dansk middelalderkonge og et stykke dansk middelalderhistorie, men også mellem deres fremstilling af henholdsvis den historiske romans og historiemaleriets funktion og hensigt. Både Ingemann og Slott-Møller havde således en tydelig national og mobiliserende ambition. Den afgørende forskel er imidlertid, at de tos værker - ligesom Cervantes' Quixote og Menards - hører hjemme i hver sin tidsalder.

Ingemann skabte sine historiske romaner i en tid, hvor Danmark var ved at komme til kræfter oven på en lang række nationale katastrofer, startende med nederlaget i Slaget på Reden i 1801: Københavns bombardement i 1807, tabet af flåden, statsbankerotten i 1813, afståelsen af Norge i 1814, landbrugskrisen fra 1818 til 1828 og den deraf følgende økonomiske lavkonjunktur. Det var i bestræbelsen på at genrejse Danmark, at Ingemann så behovet for at kalde folkeånden til live og afstive den "nationale Selvbevidsthed, som kun et anskueligt Minde om Fortiden kan fremkalde" (Ingemann 1987, 533). Den kulturelle nationalisme, som romanerne er et udtryk for, var i samtiden en stærk tendens, ikke bare herhjemme. Som allerede Brandes gjorde opmærksom på, fik Napoleonskrigene og deres følger de berørte nationer til at vende sig indad og besinde sig på deres nationale egenart, det nationale sprog, den nationale historie og den nationale kultur. ${ }^{13}$ Skønt romanerne i samtiden blev angrebet af visse kritikere, var der ingen, der for alvor satte spørgsmålstegn ved det historiske romanprojekts nationale sigte. I den forstand var Ingemann i fuld samklang med sin samtid.

Også Slott-Møller så sit værk som en "kunst båret af kærlighed til fædrelandet og dets historie". Med sit maleri ville hun "genrejse den patriotisme", som hun savnede 
i sin samtid (Overgaard 2006, 72). Som Ingemanns havde Slott-Møllers nationale projekt sine rødder i et nationalt traume - et traume, som en lovlig oppustet national selvfølelse med rette kunne siges at have bidraget til, nemlig nederlaget ved Dybbøl 1864. Det kan måske forekomme urimeligt at lægge teksterne i Nationale Værdier - som jo var blevet til i optakten til og under Første Verdenskrig - til grund for en tolkning af den senere Valdemar Sejr serie, men mange af disse tekster synes at pege direkte frem mod hendes skildring af den danske middelalderkonge. Nationale Værdier kredser uafladeligt om 1864 og om "Saarfeberen fra Dybbøl", ${ }^{\text {I4 }}$ som ifølge Slott-Møller har sat sig som en mental tilstand. Man "vendte sig bort fra det nationale og det almene", man "ønskede at glemme hele Fortiden for at kunne glemme 1864", og man ville ikke "vedkende sig Danmarkshistorien, fordi den havde ført til 1864", hedder det i "Nationale Værdier som Grundlag for en kunstnerisk Udvikling” (Slott-Møller 1917, 168). Og i essayet "1864-1914”: "det blev Skik at tale spydigt om Danmark, det var jo en Ulykke at være Dansk! [...] Danmark blev et Land uden Perspektiver, -- dets Fortid efter den sidste endelige Afgørelse lutter Skam, Tab, Nederlag" (s. 65). Fædrelandskærlighed er i disse essays en absolut og næsten religiøs værdi, og når mange af teksterne vender sig skarpt mod arbejderbevægelsen og socialdemokratiet, skyldes det ikke mindst disses i Slott-Møllers øjne forfejlede internationalisme, som hun fremstiller som endnu et udtryk for det nationale selvhad. ${ }^{15}$ I lyset af Nationale Værdier fremstår Slott-Møllers kunstneriske projekt og ikke mindst Valdemar Sejr serien som et fors $\varnothing g$ på at skabe en modfortælling til den antinationale. Betegnende nok forbigår Nationale Værdier i tavshed de stærke nationalistiske strømninger i Europa, der førte frem til Første Verdenskrig - og lagde grunden til den næste. Da Hitler kom til magten i 1933, var Slott-Møller stadig i gang med at arbejde på sin Valdemar Sejr cyklus.

Ingemanns historiske romaner er ofte, og med rette, blevet set som en blåstempling af samtidens styreform, den oplyste enevælde. Centralt i romanernes skildring af de danske middelalderkonger står imidlertid den opfattelse, at kongemagtens idé, med Birklund Andersens ord, "kun kan udfoldes i et samspil mellem konge og folk og mellem enkelt-skæbne og fælles-skæbne" (Andersen 1996, 119). Historikeren Lone Kølle Martinsen har i Ingemanns fremstilling af alliancen mellem kongen og folket set en opdateret version af myten om den oprindelige (før-feudale) bondefrihed - dvs. myten om et primitivt demokrati, hvor bonden havde ret til at stemme og besidde ejendom - som peger frem mod et lovbaseret, konstitutionelt monarki (Martinsen 2012, 110-11 og 113). Agnes Slott-Møllers kongebegejstring udfoldede sig på en anden baggrund:

(f Man taler om, at Kongemagten er indskrænket i vore Dage, at det er lykkedes at indskrænke Kongemagten, men jeg tror, at der er saa megen Natur i det Begreb Kongemagt, at det aldrig vil lykkes at indskrænke den, hvor den virkelig er tilstede. (Slott-Møller 1917, 54)

Ganske vist var det ikke kongen som politisk magtfaktor, Slott-Møller hyldede, men kongen som "Fædrelandet i Person" (s. 56). Men der var noget påfaldende ufolkeligt over hendes motivvalg - konger og dronninger, riddere og jomfruer - der synes demonstrativt ude af takt med hendes egen demokratiske og moderne tidsalder. 
Det samme kan man sige om Slott-Møllers middelalderisme generelt. Mens middelalderismen i slutningen af det 18. og begyndelsen af det 19. århundrede æstetisk set markerede brud med et klassicistisk kunstsyn, havde middelalderismen som æstetisk oprør i begyndelsen af det 20. århundrede udspillet sin rolle (Møller 2018). Ingemann var med sine fiktionaliserede skildringer af dansk middelalderhistorie på æstetisk forkant, ikke mindst rent genremæssigt. Modsat havde historiemaleriet på Slott-Møllers tid mistet en del af sin tidligere status, og hendes brug af middelalderen både som motiv og som æstetisk formsprog kan forekomme både bagudvendt og eskapistisk. Den nostalgi, som hendes billedverden er et udtryk for, er i så fald ikke blot en længsel tilbage til en før-moderne verden, men også til romantikken, Ingemanns tidsalder, og det idealiserede billede af middelalderen, den skabte. Når det er sagt, finder man hos Slott-Møller en kompromisløs vilje til at holde fast i sit eget projekt og gå mod strømmen, som det er svært ikke at beundre. Ingemann $ø$ mmede sig over den kritik, der blev hans bøger til del, men som forfatter i det tidlige 1800-tal til romaner om dansk middelalder havde han det betydelig nemmere end Agnes Slott-Møller som middelalderdyrkende historiemaler i det 20. århundrede.

\section{Noter}

I For et glimrende studie i Ingemanns metode som historisk romanforfatter se Ole Birklund Andersens kapitel om Ingemann i Den faktiske sandheds poesi (1996).

2 Det mest udførlige studie af Valdemar Seier og Ingemanns øvrige historiske romaner og versfortællinger er stadig Kjeld Galster, Ingemanns historiske Romaner og Digte fra 1922. Andre gode læsninger er Andersen (1996), Nielsen (1987), Martinsen (2012) og Gjerlevsen (under udgivelse).

3 Dronningens navn staves på mange måder. Jeg bruger Bengerd, med mindre jeg refererer til hende som karakter i Ingemanns roman, hvor hun kaldes Beengjerd.

4 For en undersøgelse af Ingemanns brug af folkeviserne i de historiske romaner se Galster (1922) og Møller (2015).

5 Denne folkevisesamling - standardudgaven frem til Svend Grundtvigs Danmarks gamle Folkevi$\operatorname{ser}(D g F)$ - har i alt syv viser med relation til Valdemar II. Foruden de fire Dagmarviser (LXVIILXX) drejer det sig om en vise om Bengerd (LXXI), en om kongen i fangenskab (LXXII) og en om han søns død (LXXIII). De relevante numre i $D g F$ er: 132-135, 139 og 141.

6 Se hertil Ingemann (1987, 533), Galster (1922, 73f) og Nielsen (1987, 508f.).

7 Oversigter over Agnes Slott-Møllers liv og kunstneriske virksomhed findes i de to store udstillingspublikationer, Agnes Slott Møller. Skønhed er til evig glæde (Overgaard (red.) 2008) og Agnes Slott-Møller. Helte og Heltinder / Heroes and Heroines (Sevel (red.) 2018). Se heri især Slott-Møller eksperten Iben Overgaards artikler (Overgaard 2008 og Overgaard 2018). For Slott-Møllers forhold til Brandes se Dahlerup (2008).

8 De to malerier er ikke medtaget i denne diskussion, da de ikke har nogen direkte pendant hos Ingemann. Unge Valdemars død nævnes kun helt kortfattet på sidste side af Valdemar Seier, mens spådommen over Bengerd-sønnerne nok er med i romanen, men i en anden udformning.

9 Se fx Slott-Møllers maleri Jomfru Blidelil (1913). Hotel Dagmar, Ribe.

Io Om Slott-Møllers rammer se Thage (2008). 
II I sin autobiografiske skitse i Nationale Værdier fortæller Slott-Møller om en barndom med en historieinteresseret far og en mor, der sang danske folkesange for børnene. Hun fortæller også om sin tidlige smag for romantisk litteratur og nævner i den forbindelse Ingemann. Et andet essay i samme værk indeholder en reference til indledningen til Valdemar den Store og hans Mænd: “Preller Ingemanns ‘Advarsel mod Udslettelsens Dom' allerede af paa dette Slægtled?” (SlottMøller 1917, 155, 158-59 og 147).

I2 Jorge Luis Borges, "Pierre Menard, Quixotes forfatter".

I3 Se Brandes (1925, 7f.).

I4 Udtrykket stammer fra Herman Bangs roman Stuk fra 1887 (Bang 1974, 220).

I5 Se især essayet "Om Fædrelandskærlighed" i Nationale Værdier, 124-36.

\section{Litteratur}

Abrahamson, Werner, Rasmus Nyerup og Knud Lyne Rahbek (red.) (1812-14): Udvalgte danske Viser fra Middelalderen, København: Schultz.

Andersen, Ole Birklund (1996): Den faktiske sandheds poesi. Studier i historieromanen i første halvdel af det 19. århundrede, Aarhus: Aarhus Universitetsforlag.

Bang, Herman (1974): Stuk, København: Gyldendal.

Borges, Jorge Luis (1989): "Pierre Menard, Quixotes forfatter”, i Fiktioner, København: Samlerens Bogklub, s. 37-51.

Brandes, Georg (1925): Hovedstrømninger i det nittende Århundredes Litteratur, bind IV, København: Jespersen og Pio.

Dahlerup, Pil (2008): "National bevidsthed og kunst, Georg Brandes og Agnes Slott-Møller”, i Iben Overgaard (red.): Agnes Slott-Møller. Skønhed er til evig glæde, Aarhus: Skovgaard Museet, Odense Bys Museer, Vejen Kunstmuseum og Øregaard Museum, s. 109-129.

Galster, Kjeld (1922): Ingemanns historiske Romaner og Digte, København: H. Aschenhoug \& Co.

Gjerlevsen, Simona Zetterberg (u.å.): "Inventing History - Fictionality in the Historical Novel in Britain and Denmark". Under udgivelse.

Grundtvig, Svend (red.) (1862): Danmarks gamle Folkeviser, bind 3, København: Samfundet til den danske Litteraturs Fremme.

Ingemann, Bernhard Severin (1913): Valdemar den Store og hans Mænd. Et historisk Digt, København: Kunstforlaget "Danmark".

Ingemann, Bernhard Severin (1987): Valdemar Seier, København: Det danske Sprog- og Litteraturselskab / Borgen.

Ingemann, Bernhard Severin (1998): Levnetsbog I-II og Tilbageblik paa mit Liv og min Forfatter-Periode fra 1811 til 1837, København: Det danske Sprog- og Litteraturselskab / C.A. Reitzel.

Lessing, Gotthold Ephraim (2004): Laokoon. Oder: Über die Grenzen der Malerei und Poesie. Project Gutenberg (online). http://www.gutenberg.org/ebooks/6889.

Martinsen, Lone Kølle (2012): “This Time as Romantic Fiction. Monarchism and Peasant Freedom in the Historical Literature of B.S. Ingemann 1824-1836", i Romantik. Journal for the Study of Romanticisms 1, s. 103-122.

Mitchell, W.J.T. (1992): “Ekphrasis and the Other”, i The South Atlantic Quarterly 91.3, s. 695-719. Møller, Lis (2015): "Refashioning the 'Marsk Stig' Ballads: B.S. Ingemann's The Childhood of Erik Menved and Carsten Hauch's Marsk Stig”, i European Romantic Review 26.4, s. 417-433. 
Møller, Lis (2018): “Agnes Slott-Møller og middelalderismen”, i Sevel, Vengberg Jakob (red.): Agnes Slott-Møller. Helte og heltinder / Heroes and heroines, Aarhus: Aros Kunstmuseum, s. 54-61.

Nielsen, Marita Akhøj (1987): "Efterskrift", i Marita Akhøj Nielsen (red.): Valdemar Seier, København: Det danske Sprog- og Litteraturselskab / Borgen, s. 505-529.

Overgaard, Iben (2006): "Valdemar Sejr som motiv - om Agnes Slott-Møllers Valdemar Sejr-serie på Nyborg Slot", i Nyborg - før \& nu 6, s. 63-78.

Overgaard, Iben (red.) (2008): Agnes Slott-Møller. Skønhed er til evig glæde, Aarhus: Skovgaard Museet, Odense Bys Museer, Vejen Kunstmuseum og Øregaard Museum.

Overgaard, Iben (2008): “Agnes Slott-Møller - med og mod tiden”, i Agnes Slott-Møller. Skønhed er til evig glæde, Aarhus: Skovgaard Museet, Odense Bys Museer, Vejen Kunstmuseum og Øregaard Museum, s. 17-73.

Overgaard, Iben (2018): "Liv og værk", i Sevel, Vengberg Jakob (red.): Agnes Slott-Møller. Helte og heltinder / Heroes and heroines, Aarhus: Aros Kunstmuseum, s. 16-24.

Sevel, Jakob Vengberg (red.) (2018): Agnes Slott-Møller. Helte og heltinder / Heroes and heroines, Aarhus: Aros Kunstmuseeum.

Slott-Møller, Agnes (1917): Nationale Værdier, København: H. Hagerups Forlag.

Slott-Møller, Agnes (1923): Folkevisebilleder, København: H. Aschehoug \& Co.

Thage, Jacob (2008): "Når intet er overladt til tilfældigheden. Om Agnes Slott-Møllers billedrammer”, i Iben Overgaard (red.): Agnes Slott-Møller. Skønhed er til evig glæde, Aarhus: Skovgaard Museet, Odense Bys Museer, Vejen Kunstmuseum og Øregaard Museum, s. 141-161.

\section{Illustrationer}

Kong Valdemar med sin Søn ved Jagtmåltidet på Lyø i Maj 1223. 1927. Olie på lærred, 263 x $481 \mathrm{~cm}$. Nyborg Slot, Østfyns Museer.

Valdemar Sejrs Hjemkomst fra Fangeskab. 1929. Olie på lærred, 139 x 311 cm. Nyborg Slot, Østfyns Museer.

Kong Valdemar og Dronning Bengerd. 1931. Olie på lærred. 240 x 214 cm. Ukendt ejer. Foto: (C) Bruun Rasmussen Kunstauktioner.

Kong Valdemars Bryllup med Dronning Dagmar. 1932. Olie på lærred, 213 x 244 cm. Ringsted Kommune. 